\title{
Policy Implementation of Tourism Development in Palembang, South Sumatra Province
}

\author{
Tri Yuniningsih ${ }^{1}$, Endang Larasati ${ }^{2}$, Ida Hayu Dwi Mawanti ${ }^{3}$ \\ \{triyuniningsih02@gmail.com ${ }^{1}$ \} \\ Universitas Diponegoro, Indonesia ${ }^{1,2,3}$
}

\begin{abstract}
Policy implementation is an action that is directed at achieving the goals outlined in policy decisions. The implementation of tourism development policies in the city of Palembang has problems of lack of socialization, lack of resources, communication that is not optimal, overlapping tasks at the implement or level. This study aims to analyze the implementation of tourism development policies in Palembang City. The research used a qualitative descriptive approach, with data collection techniques combining interviews, observation and documentation. The implementation of the Palembang City tourism development policy showed quite good results. Some of the parameters are the commitment from the government to continue to develop its tourism potential by building related infrastructure. In developing the tourism potential, Palembang City has the potential for culinary tourism.
\end{abstract}

Keywords: Tourism, Policy Implementation, Culinary Tourism, Palembang

\section{Introduction}

Tourism is one alternative to improve the economy in South Sumatra, because by developing this sector is expected many tourists who visit Palembang, which in itself will bring foreign exchange to be spent in this country to pursue the development and utilization of tourism potential region in a form of beautiful natural wealth, pluralistic traditions and cultural arts as well as historical and ancient relics.

From BPS data (2017), it can be seen that the average level of tourist visits from 20142017 who came to Palembang city where the level of visits continued to decline. This is thought to be a lack of cooperation between all the actors involved a lack of promotion and a lack of built facilities and infrastructure. In these highly demanded efforts of the local government, especially the Department of Culture and Tourism to improve further the partnership that will be increase tourist visits. Various efforts to make Palembang City a leading tourist destination in South Sumatra Province have been carried out by the city government, including promoting both domestic and international tourists. Various promotions were carried out by holding advertisements in print and electronic media but the results were not optimal. With regard to partnerships and cooperation in tourism development in the city of Palembang by referring to Law Number 10 of 2009 concerning Tourism Chapter IX, Chapter X and Chapter XI, it is felt that this is not optimal. This was conveyed by the Tourism and Culture Kadinas at the launch of the KAMBANG IWAK tourism wagon on January 11, 2019. Furthermore, he said that as one of the leading tourism cities in South Sumatra Province, it still has various potentials that can be optimized. Palembang as one of the 
provincial capitals in South Sumatra, as the second largest city after Medan, Palembang continues to improve. This development effort is an effort to attract tourists and will increase regional income from the tourism sector. In fact, the tourism potential has not been explored optimally in Palembang City.

Based on the above problems, theoretically there are indications that the implementation of tourism development policies in Palembang is not yet effective, these indications include:

1. The ineffective implementation of tourism development policies is indicated by the lack of socialization of program implementation by the stakeholders involved.

2. The lack of resources in the implementation of the program both as implementers and more resource HR, resulting in less-than-optimal implementation of the policy of development of tourism.

3. Communication which has been felt to be less than optimal in its implementation.

4. The disposition or attitude and behavior of implementing officials shows that the implementing officials are still lacking seriousness in implementing policies.

5. From the aspect of bureaucratic structures occur over la ping duties and authority among sectors required in the implementation of policies.

The research question that will be answered in this research is why the implementation of tourism development policies in Palembang City, South Sumatra Province is still not effective. Based on the above background, the research team is interested in conducting research on "Implementation of Tourism Development Policy in Palembang City, South Sumatra Province". Starting from the background of the research, the formulation of the problem can be stated as follows:

1. How does the Government of Palembang City implement Tourism Development Policy?

2. Aspects of what support and inhibit facing the Government of Palembang in implement policies Tourism Development?

\section{Literature Review}

\subsection{Policy Implementation}

According to Pressman and Wildawsky argues that: "implementation may be viewed as process of interaction between the setting of goals and action geared to achieving them". Thus, policy implementation is an option taken by stakeholders to carry out planned activities. Furthermore, Edward III [1] states that: "policy implementation is the stage of policy making between the establishment of a policy and the consequences of the policy for the people whom it affects". Meanwhile, Grindle [2] states that: "implementation - a general process of administrative action that can be investigated at a specific program level".

Thus, in relation to implementation as an activity process, its success requires regulations, the quality of human resources and administrative processes. As for who carried out these actions, Van Horn and Van Meter stated in [3] that: "those actions by public or private, individuals (groups) that are directed at the achievement of objectives set part in policy decisions". It means that the implementation process is the actions taken by individuals/officials or government or private groups that are directed towards achieving goals both organizationally and individually which are effectively outlined in policy decisions.

Thus, studying the problem of policy implementation means trying to understand what actually happens after a program is enacted or formulated, namely the events and activities 
that occur after the process of ratifying state policy, whether it involves efforts to administer it or efforts to give a certain impact on society or events.

\subsection{Implementation Model}

\subsubsection{Merilee S. Grindle Model.}

Merilee Grindle's model [2] is determined by the content of the policy and the context of its implementation. The basic idea is that once policy is transformed, policy implementation is carried out. In the Grindle [2] model the success rate is largely determined by the degree of implement ability of the policy. The content of the policy includes:

1. Interests affected by policy;

2. The types of benefits that will be generated;

3. The degree of change desired;

4. Policy maker position;

5. Program executor;

6. Deployed resources.

Meanwhile the implementation context is:

1. The power, interests, strategies of the actors involved;

2. Characteristics of institutions and authorities;

3. Compliance and responsiveness.

\subsubsection{George Edwards III Model}

Edwards III [4] states: "In our approach to the study of policy implementation, we begin in the abstract and ask: What are the preconditions for successful policy implementation? What are the primary obstacles to successful policy implementation?" To answer this important question, Edwars III [4] offers and considers four factors in implementing public policy, namely: "Communication, resources, disposition or attitudes, and bureaucratic structure".

In the policy implementation process, communication plays an important role because implementation must know what they will do. The order to implement the policy must be passed on to the apparatus, precisely and consistently. Lack of resources will result in ineffective implementation of policies. Disposition or attitude of the implementer is defined as the desire for agreement among the implementers to implement the policy. If the implementation of the policy is to be implemented effectively, the implementers not only know what they have to do and have the ability to implement it, but they must also have the desire to implement the policy. Finally, the bureaucratic structure has an impact on implementation in the sense that it will not be successful if there are deficiencies in the bureaucratic structure.

\subsubsection{Van Meter and Van Horn Models}

The most classic model introduced by Donald Van Meter and Carl Van Horn in [5], assert that: "Policy implementation runs linearly from public policy, implementer, and public policy performance". Some of the variables that are included as variables that affect and only concern in the public policy process is:

1. Implementation and communication activities between organizations; 
2. Characteristics and implementing agencies/implementers;

3. Economic, social and political conditions;

4. The tendency (disposition) of the implementer/implementers.

\section{Methodology}

This research is a descriptive qualitative research type. The data source consisted of primary data obtained from direct research informants. Determination of informants using purposive and snowball techniques. Then the data source secondary obtained through the documentation and source else who can provide information related to the focus of research. Collecting data is done with interviews and documentation online. The data analysis process adopted the thinking of Miles and Huberman in [6], namely; data condensation, data presentation, and drawing conclusions. Quality in this research, referring to the qualitative research must meet the validity of the data.

\section{Results and Discussion}

\subsection{Implementation of Palembang City Tourism Development Policy}

\subsubsection{Regulation of the Implementation of Tourism Development Policy in Palembang City}

Law of the Republic of Indonesia Number 10 of 2009 concerning Tourism. Regional Regulation of Palembang City Number 24 of 2007 concerning Tourism Business Development and Services Retribution. In the Regional Regulation of the City of Palembang Number 15 of 2012 concerning the Regional Spatial Plan (RT/RW) of Palembang City for 2012-2032, it is explained that the area on the banks of the Musi River is directed towards the development of cultural tourism, historical tourism and the development of a water front city. As well as the 2014 - 2018 Strategic Plan of the Palembang City Culture and Tourism Office.

\subsubsection{Application of Tourism Development Policy Implementation Regulation in Palembang}

The challenges faced by the Palembang City Culture and Tourism Office in service development are as follows:

a. Tourist attractions that are not yet conducive to becoming a leading destination;

b. The social and economic conditions of the community are weak against the importance of tourism in driving the wheels of the economy;

c. Lack of academic studies of cultural and historical based destinations.

Service development opportunities within the Palembang City Culture and Tourism Office is as follows:

a. There are many cultural potentials and local wisdom that can be developed as the main tourist attraction;

b. There are many regional, national and international events held in Palembang City; 
c. The establishment of Palembang City as one of the Tourist Destination Destinations and MICE Implementation in Indonesia and is part of the Indonesian Heritage City Network (JKPI).

\subsection{Supporting and Obstacles to the Implementation of Palembang City Tourism Development Policy}

\subsubsection{Content of the Policy}

\subsubsection{Benefits of Tourism Development Policy}

The success of implementation is very much determined by the content of the policy, namely how much the interests are affected, the greater the interests are affected, the more difficult the implementation will be Grindle [7] In implementing tourism development policies in Palembang City, the benefits are reflected in the policy objectives, including;

1. Making Musi River a Leading Destination that has competitiveness and quality;

2. Making sites, objects and buildings of historical value and cultural customs as the identity of Palembang City;

3. Increasing public welfare through tourism and cultural activities;

4. The realization of Palembang as one of the leading tourist destinations in Indonesia;

5. Creating a tourism awareness community in supporting sapta charm.

\subsubsection{The Degree of Change Desired from Tourism Development}

How much change is expected from the policy becomes one of the parameters for assessing policy implementation. Changes based on changes in attitudes and behavior covering a large enough area requires more difficult implementation than changes covering a narrow area. The degree of change is in accordance with policy objectives, including;

1. The availability of qualified and professional human resources in the field of tourism and culture;

2. Availability of Representative Tourism Facilities and Infrastructure;

3. The increase in the percentage of the tourism sector's contribution to GRDP;

4. Increased development of cultural diversity;

5. Increased partnerships in tourism development.

\subsubsection{Policy Context}

\subsubsection{Powers, Interests and Strategies of Actors in Implementing Policies}

In order to achieve the goals and objectives of the Palembang City Culture and Tourism Office, the following strategies and policies are set:

1. Strategy
a. Development of Tourist Attractions in strategic areas along the banks of the Musi River;
b. Increased Actualization of Local Culture and Wisdom;
c. Improvement of Community Welfare through Tourism Activities;
d. Increased tourism promotion;
e. Partnership Enhancement. 
2. Policy

a. Increasing Revitalization and Strengthening Position of Historical Areas and Conservation of Cultural Heritage;

b. Developing the Beauty of Local Culture with Character and Personality as the Identity of Palembang City;

c. Driving a Community Economic Wheel Based on Cultural Values that Live in the Community;

d. Increasing the Promotion and Publication of Tourism through Various Media and Organizing Events and Direct Promotions outside the Region;

e. Improve Partnership Management and Cooperation;

f. Development of Tourist Attractions with All People.

\subsubsection{The Influence of Economic, Political, Socio-Cultural Conditions in Policy Implementation}

Economically, tourism development is adjusted to the Regional Budget and the strategic plan for the development of Palembang City which means that tourism development is one of the economic priorities in the regional development of Palembang City. Besides that, considering that the development of tourism is expected to be able to increase people's income through creative industries both in culinary and souvenir businesses. In political conditions, the preparation of the Palembang City Tourism Development Strategic Plan certainly goes through the approval stage from the legislative body, namely the Palembang City DPRD. This suggests that the development of tourism in Wyoming is not fitting condition to the ongoing political dynamics. The tourism development in Palembang City is also integrated with the socio-cultural conditions where the potential for tourism is often adjusted to the local culture, as well as the social habits of the community which become the characteristics and identity of an area.

\subsubsection{The Attitudes and Abilities of the Implementer}

\subsubsection{Ability's the Policy Implementers}

Implementing the Palembang City tourism development policy is aimed at employees who are under the auspices of the Culture and Tourism Office. This means that in their ability, the executors perform according to their main tasks and functions. In his observations, the administrative capacity of the implementers is already good. However, they have not been able to make innovations related to tourism development in Palembang City. Not yet have the breakthrough ability in the development of tourism in Palembang City.

\subsubsection{Commitment of the Policy Implementers}

The policy implementers have a commitment in accordance with their main duties and functions as employees of the Palembang City Culture and Tourism Office. With regard to the attitude and ability of the implementers of tourism development policies, this commitment is able to support the performance of local governments in implementing their strategic plans. But it would be nice, this commitment needs to be developed by making a real contribution to the development of tourism in Palembang City. 


\subsubsection{Communication}

\subsubsection{Knowledge of Policy Implementers}

Knowledge of policy implementers will influence decisions and actions in their implementation. In the development of tourism in Palembang City, implementers gain knowledge in accordance with their main duties and functions as employees of the Palembang City Culture and Tourism Office. This knowledge is obtained from hierarchical orders according to the flow of the organizational structure as well as in coordination meetings during the discussion of tourism development in Palembang City.

\subsubsection{Media or Transmission Used in the Implementation of the Policy}

Promotion media and publications in Palembang are needed by the public and the city of Palembang already has several mass media that can be used as references for you to promote or seek complete information, including Sumatra Express, Sriwijaya Post, Morning News, Pal TV, Sriwijaya TV. As well as specifically the Palembang City tourism office also provides tourism information through the portal or website palembang-tourism.com

\subsubsection{Resources}

\subsubsection{Availability in Quantity and Quality of Policy Implementers}

The apparatus resources of the Palembang City Culture and Tourism Office were recorded that up to October 2013, there were 73 civil servants and 59 volunteer workers. About a third is undergraduate graduates. The suitability of the level of education will have a major impact on performance which in turn will be able to encourage the implementation of tourism development policies in Palembang City.

\subsubsection{The Condition of Facilities and Infrastructure of a Supporting Policy Implementation, Including Infrastructure}

Technically, the facilities and infrastructure for implementing tourism development policies in Palembang City are not only internal facilities for the Palembang City Tourism Office, but also include infrastructure facilities, lodging and transportation services. With so many events being held in Palembang, both national and international events, it provides an opportunity for this city to become one of the objectives of the MICE (Meeting, Incentives, Convention and Exhibition) implementation.

\subsubsection{Bureaucratic Structure}

\subsubsection{Standard Operating Procedures for Implementing Policies}

In implementing the Palembang City tourism development policy, operational standards and procedures are in accordance with the hierarchical structure of the Palembang City Culture and Tourism Office. In the organizational structure, implementation procedures are adjusted to the main tasks and functions of each field. With this hierarchical level, of course, a managerial flow of implementation will be seen from top to bottom. There are planners, implementers, supervisors and an internal evaluation team. With this division of tasks, the 
implementation of tourism development policies can at least be planned to implement the work program, as well as continue to be monitored and evaluated to consistently maintain the implementation of policies to achieve the goals that have been formulated.

\subsubsection{Fragmentation of the Bureaucratic Policy Implementation}

In implementing the tourism development policy in Palembang City, the Palembang City Culture and Tourism Office is the agency involved in accordance with its bureaucratic structure. This fragmentation is reflected based on its main duties and functions, which are specifically located in the area under the auspices of the Cultural Development Sector, the Tourism Facilities and Services Sector, the Tourism Marketing Sector and the Tourism Object and Attraction Sector.

\subsubsection{Forms of Cooperation and Coordination Among Policy Implementers}

The Palembang City Tourism Office coordinates and collaborates with several related agencies both in the central, regional and tourism organizations in the city of Palembang, such as Public Relations and Protocols of the Palembang City Regional Secretariat, the Palembang City Planning and Regional Development Agency, the Industry Service and trade, Cooperatives Palembang, Indonesia Investment Coordinating Board areas of the cities of Palembang, the Department of Transportation, the city of Palembang, the Office of Communications and Information of Palembang city, the Department of Education and Youth Sports Palembang, Office of Integrated Licensing Services (KPPT) of Palembang, the Ministry of Tourism and Creative Economy, Department of Culture and Tourism of South Sumatra Province, Organization of PHRI of South Sumatra Province, Organization of ASITA of South Sumatra Province.

\section{Conclusion}

The implementation of the Palembang City tourism development policy showed quite good results. Some of the parameters that are the commitment of the government to continue to expand k's tourism potential by developing related infrastructure. In developing the tourism potential, Palembang City has the potential for culinary tourism. The culinary offered by the city of Palembang is an amalgamation of typical Palembang cuisine, with cuisines from other cities, however, it is very popular with the people of Palembang so that it has become a famous food in the city of Palembang.

The following are aspects of the implementation of the Palembang City tourism development policy, which have been classified as supporting factors because it has been running well and inhibiting factors because it has not been implemented optimally:

1. Supporting factors
a. Content of policy.
b. Policy Context.
c. Resource.

2. Obstacle factor
a. Attitude and executor ability.
b. Communication.
c. Bureaucratic structure. 
In accordance with the findings of research formulated in the inhibiting factors for the implementation of the Palembang City tourism development policy, the following recommendations are compiled:

1. It is necessary to increase the competence of policy implementers, by conducting special coaching and training or comparative studies to pilot areas for better tourism development patterns.

2. The importance of optimizing the use of information technology media, by actively promoting activities through social media such as Twitter, Instagram and YouTube.

There is a need for actor network analysis as an effort to map the components involved and support tourism development.

\section{References}

[1] T. Wright and E. Benoit III, “Technology Use in Designing Curriculum for Archivists: Utilizing Andragogical Approaches in Designing Digital Learning Environments for Archives Professional Development," Preserv. Digit. Technol. Cult., vol. 48, no. 2, pp. 85-94, 2019.

[2] M. S. Grindle, Getting good government: capacity building in the public sectors of developing countries. Harvard Univ Pr, 1997.

[3] S. A. Abdul-Wahab, "A preliminary investigation into the environmental awareness of the Omani public and their willingness to protect the environment," Am. J. Environ. Sci., vol. 4, no. 1, pp. 39-49, 2008.

[4] G. C. Edwards, Implementing public policy. Congressional Quarterly Press, 1980.

[5] R. Nugroho, "Kebijakan publik: Formulasi, implementasi dan evaluasi," Jakarta Elex Media Komputindo, 2003.

[6] Sugiyono, Metode Penelitian Kuantitatif, Kualitatif, dan Kombinasi, Alfa Beta. Bandung, 2012.

[7] M. S. Grindle, Politics and policy implementation in the Third World, vol. 4880. Princeton University Press, 1980. 